\title{
ОСОБЛИВОСТІ ХІРУРГГЧНОГО ТА КОМБІНОВАНОГО ЛІКУВАННЯ МЕДУЛОБЛАСТОМ МОЗОЧКА У ДІТЕЙ МОЛОДШОГО ВІКУ
}

\section{B. В. Моргун \\ Інститут нейрохірургії імені А. П. Ромоданова НАМН України, м. Київ \\ PECULIARITIES OF SURGICAL AND COMBINED TREATMENT OF THE CEREBELLUM MEDULLOBLASTOMA IN CHILDREN OF EARLY AGE}

\author{
V. V. Morgun \\ Romodanov Institute of Neurosurgery, Kyiv
}

\begin{abstract}
Реферат
Медулобластоми мозочка (ММ) є високозлоякісними ембріональними пухлинами головного мозку, що діагностують переважно у дітей, характеризуються раннім метастазуванням. Дані літератури свідчать про особливості перебігу та результатів лікування ММ у дітей різного віку.

Матеріали і методи. Проаналізовані результати лікування 297 дітей різного віку з приводу ММ. В усіх дітей видаляли пухлину та проводили ад'ювантну терапію у різному обсязі.

Результати. Тотальне видалення пухлини здійснене у 40,6\% хворих, субтотальне- у 53,6\%, часткове чи біопсія- у 5,8\%. У 71 $(25,5 \%)$ хворих видалення пухлини доповнене лікворошунтувальними операціями. У строки до 30 днів після видалення пухлини помер 31 (10,8\%) хворий. Медіана виживання дітей віком до 3 років становила 12- 18 міс залежно від обсягу лікування, дітей старшого віку- 24- 36 міс.

Висновки. Тотальне видалення пухлин виявилося можливим у 40,3\% дітей молодшого віку, субтотальне- у $42 \%$. У дітей віком до 3 років гірший прогноз виживання.

Ключові слова: медулобластома; хірургічне лікування; результати; діти.

Abstract

Medullobastoma of cerebellum (MC) constitutes a highly malignant embryonic cerebral tumor, diagnosed mainly in children, it is characterized by early metastasizing. The literature data witness peculiarities of clinical course and results of treatment for MC in children of various age.

Materials and methods. Results of treatment of 297 children of various age for MC were analyzed. In all the children the tumor was excised with adjuvant therapy of different volume.

Results. Total excision of tumor was done in $40.6 \%$ patients, a subtotal one- in $53.6 \%$, partial excision or biopsy-in $5.8 \%$. In 71 (25.5\%) patients the tumor excision was added by liquoroshunting procedures. In immediate postoperative period ( 30 days) after the tumor excision $31(10.8 \%)$ patients died. The survival median in children ageing up to 3 years old have constituted $12-18$ mo, depending on the treatment volume, and for more mature children-24-36 mo.

Conclusion. Total excision of the tumors have appeared possible in $40.3 \%$ of the early age children, a subtotal one- in $42 \%$. In children ageing up to 3 years old a survival prognosis is worse.

Keywords: medulloblastoma; surgical treatment; results; children.
\end{abstract}

Медулобластоми- найбільш часті ембріональні пухлини дитячого віку. Підвищення радикальності хірургічного втручання та доповнення його ад'ювантними методами дозволило покращити показники виживання хворих віком старше 3 років з Мм, у дітей молодшого віку, незважаючи на застосування різних режимів поліхіміотерапіі, в тому числі високодозової, з підтримкою периферійними стовбуровими клітинами, якість і тривалість життя низькі [1-5].

Мета дослідження: порівняти результати хірургічного та комбінованого лікування ММ у дітей молодшого і старшого віку, провести порівняльну оцінку перебігу ММ у дітей 3 огляду на вік хворих, локалізацію пухлини, частоту метастазування, результати хірургічного і комбінованого лікування, показники виживання.

\section{МАТЕРІАЛИ I МЕТОДИ ДОСЛІДЖЕННЯ}

Проаналізовані результати лікування 297 хворих з приводу ММ у відділі нейрохірургії дитячого віку в період 1990- 2014 рр. Вік дітей від 2 тиж до 18 років. Віком від 0 до 3 років було $33(11,1 \%)$ дитини, від 3 до 7 років- 97 (32,6\%), від 7 до 11 років114 (38,4\%), від 12 до 18 років- 33 $(11,1 \%)$.

Типовою локалізацією пухлин був черв'як мозочка- у 247 (81,3\%) хворих, рідше- півкулі мозочка- у 34
$(11,4 \%)$. У 96,8\% спостережень пухлини були солідними, у 3,2\%- кістозними. Гідроцефалія виявлена у 247 $(88,8 \%)$ пацієнтів. Комп'ютерна томографія проведена у 70 хворих, магніторезонансна томографія- у $52,1 \%$.

Всі пацієнти оперовані. Тотальне видалення пухлин виявилося можливим у 40,3\% дітей молодшого віку, субтотальне- у 42\%, у 17,7\%- здійснене часткове видалення чи біопсія пухлини. У дітей старшого віку тотальне видалення пухлини виконане у 40,6\%, субтотальне- у 53,6\%, часткове та біопсія- у 5,8\%. Фактором, що обмежував радикальність видалення пухлини, було іiі вростання у стовбур мозку. 
В усіх спостереженнях діагноз верифікований за даними гістологічного дослідження. У 71 (25,5\%) хворого видалення пухлини доповнене лікворошунтувальними операціями. Результати лікування аналізували у строки від 1 міс до 10 років у 230 (82,7\%) дітей. Медіана виживання дітей віком до 3 років становила 1218 міс, залежно від об'єму ад'ювантної терапії, у дітей старшого віку24- 36 міс. Результати дослідження оброблені статистично.

\section{РЕЗУЛЬТАТИ}

\section{ТА ÏХ ОБГОВОРЕННЯ}

Результати хірургічного та комбінованого лікування ММ оцінювали на підставі даних про локалізацію пухлини, до- та інтраопераційних показників, що дало можливість провести стадіювання MM за Chang у дітей різного віку (табл. 1) [6].

За результатами дослідження, пухлина діаметром понад 3 см виявлена більш ніж у 80\% хворих, переважно проростала IV шлуночок, поширювалась на прилеглі структури. Пухлина проростала стовбур мозку у 33,7\% хворих. Аналіз цих показників свідчив про певні відмінності, що чітко проявлялись у дітей молодшого віку.

У дітей молодшого віку переважали ММ у стадії Т2 і Т3а, пухлини розташовані у черв'яку мозочка, з частковим блокуванням IV шлуночка, рідше- поширені у водопровід великого мозку та серединну чи латеральну апертуру IV шлуночка (отво- ри Мажанді чи Люшка, у 54,5\%); порівняно рідко (у 6\%) в процес був включений стовбур мозку (стадія Т3); менш часто- (у 18,1\%) поширювались супратенторіально в III шлуночок і / або в хребтовий канал (стадія Т4). У хворих віком від 4 до 18 років не виявляли значних внутрішньогрупових відмінностей локалізації пухлин, що корелювало з даними попередніх досліджень $[1,4]$.

$\mathrm{y}$ дітей старшого віку переважали ММ у стадії Тза і Т3b, коли пухлина не тільки тампонувала IV шлуночок, а й вростала у водопровід великого мозку та структури стовбура (до 70\%). Можна стверджувати, що у дітей молодшого віку розташування ММ більш сприятливе для їх радикального видалення.

Гістологічну верифікацію діагнозу ММ проводили відповідно до класифікацій ВОО3 $(2007,2016)$ у відділі патоморфології [7].

За результатами гістологічного дослідження виявлені особливості ММ у дітей різного віку: так, в групі від 0 до 3 років «класична» ММ виявлена у 14 (42,4\%) хворих, десмопластична- у 5 (15,1\%), анапластична- у 9 (27,3\%), змішані форми- у 5 (15,1\%). У групі від 3 до 7 років «класична» ММ виявлена у 63 (65\%) хворих, десмопластична- у 13 (13,4\%), анапластична- у 17 (17,5\%), змішані форми- у 4 (4,1\% ). У групі від 7 до 11 років «класична» ММ відзначена у 86 (75,4\%) дітей, десмопластична- у 17 (14,9\%), анапластична- у 7 (6,1\%), змішана-у 4 (3,5\% ). У групі від 12 до
18 років «класична» ММ виявлена у 45 (84,9\%) дітей, десмопластичнау 4 (7,5\%), анапластична- у 2 (3,7\%), змішана- у 2 (3,7\%). Тобто, у дітей віком до 3 років переважали анапластична та «класична» ММ, що характеризувалися більш агресивним перебігом, раннім метастазуванням та гіршим прогнозом. Таку тенденцію відзначали й інші автори [2- 5, 8, 9].

Другою важливою складовою стадіювання MM за Chang $є$ визначення стадії метастазування на момент операції у хворих різного віку (табл. 2).

Не беручи до уваги вік дітей, частота метастазування становила 17,6\%, переважала стадія M2 (55,8\% всіх спостережень метастазування). У дітей молодшої групи частота метастазування становила 18,0\%, у більш старших- від 10 до 15,2\%, у середньому- $13,8 \%$. У середньому у молодшій групі стадія М1 відзначена у 9,7\%, м2- у 3,5\%, М3- в 1,7\% хворих; у більш старших групах- відповідно у $6,0,5,1$ та $1,7 \%$.

У строки до 30 днів після видалення пухлини помер 31 (10,8\%) хворий. Основною причиною летального наслідку були: набряк стовбура головного мозку і гіпоталамусу-у 20 $(68,4 \%)$ хворих, крововилив у залишки пухлини- у 10 (26,3\%), позамозкові ускладнення-в 1 (5,3\%).

Зменшення летальності певним чином корелює з збільшенням радикальності втручання: за тотального видалення пухлини вона становила $6,2 \%$, субтотального- $12,2 \%$, частко-

Таблиця 1. Розподіл дітей з ММ залежно від віку та стадії за Chang

\begin{tabular}{|c|c|c|c|c|c|c|c|c|c|c|c|c|c|}
\hline \multirow{3}{*}{$\begin{array}{c}\text { Група } \\
\text { хворих }\end{array}$} & \multirow{3}{*}{$\begin{array}{c}\text { Вік, } \\
\text { років }\end{array}$} & \multicolumn{12}{|c|}{ Кількість спостережень за стадії пухлини } \\
\hline & & \multicolumn{2}{|c|}{$\mathrm{T} 1$} & \multicolumn{2}{|c|}{$\mathrm{T} 2$} & \multicolumn{2}{|c|}{ T3a } & \multicolumn{2}{|c|}{ T3в } & \multicolumn{2}{|c|}{ T4 } & \multicolumn{2}{|c|}{ Разом } \\
\hline & & абс. & $\%$ & абс. & $\%$ & абс. & $\%$ & абс. & $\%$ & абс. & $\%$ & абс. & $\%$ \\
\hline 1-ша & $0-3$ & 1 & 0,3 & 9 & 3,2 & 9 & $3,2^{*}$ & 2 & 0,8 & 6 & 2,2 & 33 & 9,7 \\
\hline 2-га & $3-7$ & 2 & 0,8 & 13 & 4,7 & 46 & $16,5^{*}$ & 23 & 8,3 & 3 & 1,1 & 97 & 31,4 \\
\hline 3-тя & $7-11$ & 1 & 0,3 & 19 & 6,8 & 46 & $16,5^{*}$ & 42 & 15,1 & 8 & 2,8 & 114 & 41,5 \\
\hline 4-та & $2-18$ & 1 & 0,3 & 10 & 3,6 & 18 & $6,6^{*}$ & 15 & 5,5 & 4 & 1,4 & 53 & 17,4 \\
\hline Загалом ... & & 5 & 1,7 & 51 & 18,3 & 119 & 42,8 & 82 & 29,7 & 21 & 7,5 & 297 & 100 \\
\hline
\end{tabular}

Таблиця 2. Стадії метастазування МБ за Chang у різних вікових групах

\begin{tabular}{|c|c|c|c|c|c|c|c|c|c|c|c|c|c|}
\hline \multirow{3}{*}{$\begin{array}{c}\text { Група } \\
\text { хворих }\end{array}$} & \multirow{3}{*}{$\begin{array}{c}\text { Вік, } \\
\text { років }\end{array}$} & \multicolumn{12}{|c|}{ Кількість спостережень за стадії метастазування } \\
\hline & & \multicolumn{2}{|c|}{ MO } & \multicolumn{2}{|c|}{ M1 } & \multicolumn{2}{|c|}{$\mathrm{M} 2$} & \multicolumn{2}{|c|}{$\mathrm{M} 3$} & \multicolumn{2}{|c|}{ M4 } & \multicolumn{2}{|c|}{ Разом } \\
\hline & & абс. & $\%$ & абс. & $\%$ & абс. & $\%$ & абс. & $\%$ & абс. & $\%$ & абс. & $\%$ \\
\hline 1-ша & $0-3$ & 23 & 8,2 & 1 & 0,3 & 3 & 1,2 & - & - & - & - & 33 & 9,7 \\
\hline 2-га & $3-7$ & 74 & 26,7 & 5 & 1,4 & 10 & 2,1 & 3 & 1,2 & - & - & 97 & 31,4 \\
\hline 3-тя & $7-11$ & 106 & 38,2 & 8 & 1,4 & 3 & 1,2 & 2 & 0,7 & - & - & 114 & 41,5 \\
\hline 4-та & $2-18$ & 42 & 15,1 & 8 & 0,7 & 8 & 1,3 & 1 & 0,3 & - & - & 53 & 17,4 \\
\hline Загалом ... & & 245 & 88,2 & 22 & 3,8 & 24 & 5,8 & 6 & 2,2 & - & - & 297 & 100 \\
\hline
\end{tabular}


вого- 44,1\%. У дітей віком до 3 років відзначали меншу післяопераційну летальність після субтотального, ніж після тотального видалення пухлини, що можна пояснити меншим ризиком порушення кровообігу у стовбурових структурах мозку.

Комбіноване лікування ММ після хірургічного втручання проводили відповідно до протоколів, затверджених наказом МО3 України № 649 від 28.09.2009 р. «Про затвердження клінічних протоколів лікування дітей 3 солідними новоутвореннями». Протокол комбінованого лікування дітей старше 3 років включав залежно від періоду спостереження поліхіміотерапію і опромінення всього аксиса за протоколами НIT91, HIT-2000, P-HIT 2000-BIS4, PB /02-04, SKK'92-00. Дітям віком до 3 років проводили хіміотерапію (XT) за протоколом МЕT-HIT 2000-BIS4, вводили карбоплатин і етопозид, а за «позитивної відповіді»- додатково тіотеру і циклофосфан.

Променева терапія проведена 186 (66,9\%) дітям, у тому числі 8 (2,9\%)віком від 1,5 до 3 років, після тотального або субтотального видалення пухлини. ХТ проведена 94 (33,8\%) дітям, у тому числі 14 (5\%) віком від 0,5 до 3 років, після тотального і субтотального видалення пухлини.

Результати лікування простежені у 230 (82,7\%) дітей у строки від 1 міс до 10 років. У дітей віком до 3 років медіана виживання становила 12 міс- при виконанні лише хірургічного втручання, 18 міс- при додаванні одного 3 методів ад’ювантної терапії. У дітей старшого віку медіана виживання становила 24 міс- за неповного виконання протоколів лікування, 36 міс- при проведенні ад'ювантної терапії у повному обсязі.

Продовжений ріст пухлини або метастазування відзначене у 88 (38,2\%) хворих, переважно впродовж першого року після операціїу (53,5\%), у подальшому цей показник значно зменшувався: на другий рік- у 22,5\%, третій- у 7,5\%, п'ятийy $6,2 \%$.

При аналізі показників виживання залежно від радикальності операції та обсягу ад’ювантної терапії виявлені певні закономірності. За тотального і субтотального видалення пухлини показники істотно не різнилися, негативний вплив на показники виживання справляло іiі часткове видалення. Це підтверджують й інші дослідники [5, 6, 8-10]. За нашими даними, протягом 1 року жили 73\% пацієнтів, незалежно від радикальності операції; 2 років після тотального і субтотального видалення пухлини- $42 \%$, часткового- $25 \%$; 5 років після тотального видалення$8,3 \%$, субтотального- $2 \%$, після часткового видалення пухлини до 5 років не дожив жодний хворий.

Таким чином, особливості перебігу ММ у дітей різного віку потребують подальшого вивчення. За да- ними дослідження, у дітей молодшого віку локалізація ММ дозволяє більш часто застосовувати ї радикальне видалення, проте, відносно більша частота часткового видалення, раннього метастазування і неповний обсяг ад'ювантної терапії (без променевого лікування) нівелюють вплив радикальності операції на тривалість виживання, що дає підстави вважати обсяг ад’ювантної терапії одним з основних чинників, що впливають на медіану виживання і якість життя дітей раннього віку.

\section{вИсновки}

1. За даними проведеного дослідження встановлено, що перебіг ММ має особливості у дітей різного віку, особливо молодшого віку.

2. У дітей віком до 3 років частіше спостерігали сприятливе для радикального видалення розташування пухлин. Тотальне видалення пухлин здійснене у 40,3\% дітей раннього віку, субтотальне- у $42 \%$.

3. Вірогідних відмінностей частоти раннього метастазування у дітей різного віку не було, хоча вона дещо більша у дітей молодшого віку.

4. Менші показники виживання дітей молодшого віку, ймовірно, зумовлені меншим обсягом ад’ювантної терапії порівняно з такою у дітей старшого віку.

\section{REFERENCES}

1. Shaverskiy AV, Orlov YuA, Mikhalyuk VS, i dr. Diagnostika i lechenie medulloblastom mozzhechka u detey. Zbirnyk naukovykh statei spivrobitnykiv NMAPO ym. P. L. Shupyka. 2013;(22):34-41. [In Russian].

2. Gorelyshev SK, Mentkevich GL, Mazerkina NA, Trunin YuYu, Kholodov BV, Khukhlaeva EA, i dr. Klinicheskie rekomendatsii. Standarty lecheniya medulloblastom u detey starshe 4 let. Moskva; 2014. 19 s. [In Russian].

3. Medvedeva OA, Gorelyshev SK, Mazerkina NA. Kompleksnoe lechenie medulloblastom u detey. Neyrokhirurgiya i nevrologiya detskogo vozrasta. 2016;(16):45-56. [In Russian].

4. Shaverskyi AV. Pukhlyny holovnoho mozku u ditei molodshoho viku [tezy]: Kyiv; 2015. 28 c. [In Ukrainian].

5. Coluccia D, Figuereido C, Isik S, et al. Medulloblastoma: Tumor biology and revelance to treatment and prognosis paradigm. Curr Neurol Neurosci Rep. 2016 May;16(5):43.doi:10.1007/s11910-016-06447. PMID: 27021772.

6. Chang C, Housepian E, Herbert C. An operative staging system and a megavoltage radiotherapeutic technique for cerebellar medulloblastoma. Radiology. 1969;93: 1351-9.
7. Louis D, Perry A, Reifenberger G, von Deimling A, Figarella-Branger D, Cavenee WK, et al. The 2016 WHO Classification of Tumours of the Central Nervous System: a summary. Acta Neuropathol. 2016;131(6):803-20. doi 10.1007/s00401-016-1545-1.

8. Ashley DM, Merchant TE, Strother D, Zhou T, Duffner P. Induction chemotherapy and conformal radiation therapy for very young children with nonmetastatic medulloblastoma: Children's Oncology Group Study P9934. J Clin Oncol. 2012 Sep 10;30(26):3181-6. doi: 10.1200/JCO.2010.34.4341 PMCID: PMC3434977

9. Northcott PA, Jones DTW, Kool M. Medulloblastomics: the end of the beginning. Nat Rev Cancer. 2012 Dec;12(12):818-34. PMCID PMC3889646 NIHMSID: IHMS440649/

10. Schreiber JE, Gurney JG, Palmer SL, Bass JK, Wang M, Si Chen, et al. Examination of risk factors for intellectual and academic outcomes following treatment for pediatric medulloblastoma. Neuro Oncol. 2014 Aug;16(8):1129-36. doi 10.1093/neuonc/nou006.- PMCID: PMC4096173. 